\title{
Reflexive Interactive Design and its application in a project on sustainable dairy husbandry systems
}

\author{
Bram Bos, Peter Groot Koerkmap, Jules Gosselink, Sjoerd Bokma \\ ASG WUR, Lelystad, The Netherlands-bram.bos@wur.nl
}

\begin{abstract}
Sustainable development in modern animal husbandry has to deal with multiple challenges, like its environmental foot print, the welfare of animals, labour issues and economical rentability. If solved separately, they might very well contradict each other. To circumvent this, structural change of our production and consumption systems is required. This cannot be attained by mere technical innovation alone, but asks for a reorientation of the existing sociotechnical regime, that shapes current practice. In this paper we present Reflexive Interactive Design (RIO) as a systematic approach to do this, and show its application in an ongoing project to deliver designs for sustainable dairy production, and to contribute to the effective reformation of the current dairy production system.

RIO aims to increase the chance of structural change in existing systems, necessary to solve a number of sustainability issues at the same time. RIO is built upon three pillars: 1. systematic reflexion on the current structural arrangements of the system and the needs of key actors involved (system analysis). 2. designing new systems or structural arrangements using a systematic design approach (structured design), and; 3. strategically using concepts and reflexions to attain effective reformism (anticipation on existing structures).

We describe the application of RIO in a project running since 2007 aimed at the development of sustainable husbandry systems for dairy cows in the Netherlands. We will show how a systematic reflexion on the structure of the current system contributes to opening up both the problem and solution space, and how this opening up is funneled down to proposals for new structural arrangements. Later, these proposals will be elaborated in full-fledged concepts by means of a systematic design methodology. The function of interaction and reflexion in these separate steps of the design process will be highlighted, as well as the central role of needs.
\end{abstract}

Keywords: sustainable development, reflexive interactive design, method, system innovation, dairy

\section{The challenge of sustainable development in animal husbandry}

Animal husbandry in North Western Europe faces a variety of problems created by its own modernization process - problems regarding ecology, economy and animal welfare and health. Pressure from society, politics, and a globalizing market force the sector and its periphery to reflect on a number of basic tenets and presuppositions, that have laid the basis for its enormous success of the last three to four decades. Success here is defined as a continuous increase in production volume against continuously decreasing costs through efficiency improvement of inputs. This result of first modernization (Beck 1992) is increasingly confronted with its self-generated and undesirable side effects, that limit the continuation of 'business as usual'. The EU agricultural policy had a major influence on this modernization and the recent and foreseen changes in het CAP (Common Agricultural Policy) reflect the undesirable side effects.

For the last two and a half decades, the public debate on animal husbandry tended to focus on single issues. Firstly, the scientific notion of reduced welfare of animals in the newly developed housing systems in the seventies. Secondly, its impact on the local environmental in the early eighties. Thirdly, susceptibility to infectious diseases in the nineties. Fourthly, the quality of life of the animals themselves as perceived by society in the beginning of the twenty-first century. And fifthly, the foreseen finiteness of the current way pathogenic diseases are dealt with on production farms, i.e. the high use of antibiotics and vaccines. Each of these could still be seen as singular problems, that could be solved one by one by adequate technological and institutional measures. However, in recent years, each of these aspects has come under scrutiny simultaneously, and is complemented by new issues like the depletion of tropical forests, the considerable contribution of animal production to climate change, and its world wide water use. Taken together, these issues raise fundamental questions on the basic assumptions and structural choices on which this Dutch production system has been built 
after World War II. However, this European picture seems valid for many intensive animal production systems world wide.

\section{Public debate on animal husbandry in the Netherlands}

This can be identified also in the character and scope of public debate in the Netherlands. Awareness is growing that the future face of animal production should be (much) more sustainable than it is today, and on several dimensions. Recent examples for this include the Citizens Initiative 'Stop fout vlees' (Milieudefensie and JMA 2007), an appeal to the Dutch Parliament signed by 106.975 citizens, the long term vision of the Dutch minister of agriculture on sustainable animal husbandry (Verburg 2008), and the movie 'Meat the truth' (Thieme 2007) of the Dutch political party Partij voor de Dieren dealing with the links between meat consumption and climate change. Of course, a basic disagreement may exist on the fundamental question whether animal production for human consumption is legitimate in itself. However, the vast majority of citizens and stakeholders in the Netherlands still affirms this basic premise. And as far as we can observe, this majority does not disagree on what sustainability should ideally imply in the long run: an economically feasible production of animal derived food without passing the costs of it to those who do not benefit from it, for instance by harming animals, damaging local communities, environmental impact through high losses and depleting local and global resources like soil, energy and water. However, what this means for the future character of Dutch animal husbandry is less clear, and currently food for fierce societal debate. Animal rights activists and environmental groups join forces for a considerable reduction and extensification of national production, to mitigate its global ecological footprint and improve on animal welfare (Milieudefensie and JMA 2007; Thieme 2007). The sector, and the national government (Verburg 2008) operate from the assumption that it is still possible -and even necessary- to maintain the current level of production in a much more sustainable way, by the development of new technology, an adaptation of current husbandry systems and the development of new markets with higher added value. They, and others (for instance (Steinfeld et al. 2006) stress the enormous increase in world wide demand for food (both of vegetable and animal origin), as prosperity and populations grow. This trend in itself forces us to increase efficiency of our food production systems, and reduce the environmental burden at least by half (Weaver et al. 2000); (Steinfeld et al. 2006). Thus, as long as world wide demand for animal products increases, and consumption patterns do not dramatically change in favour of vegetable proteins, sustainability in animal production cannot be reached by a mere reduction of production in the Netherlands alone.

This division of minds shows that the character of sustainability in animal production cannot be defined straightforwardly, and does have inherently normative and political components, that might require hard choices between conflicting interests. We want to argue however, that these conflicting interests should not be the point of departure, since they themselves are the result of the (historically contingent) co-evolution of values, practices and institutions in livestock production. Taking them as given would make them more absolute and irresolvable than they possibly are, especially if we adopt a longer time horizon. Instead, it might be more fruitful to interpret the wide array of perspectives on livestock production as an expression of the fact that very basic tenets of the production system (its structure and functions, related consumption patterns, global dependencies) have become subject for re-evaluation. Animal husbandry has entered the stage of reflexive modernization in risk society - a stage in which dealing with its self-generated risks cannot be successfully done in the same way as it has evolved in its current form in first modernization.

\section{Reflexive modernisation}

The idea of reflexive modernization (Beck 1997; Beck, Giddens, and Lash 1994; Beck, Bonss, and Lau 2003) has a descriptive as well as a prescriptive character. In order to distinguish these, Latour (Latour 2003) proposes the term re-modernization to indicate the (postulated) empirical phenomenon. Descriptively, the notion suggests that modern society is forced to reflect on the basic assumptions that structured first modernization. Whether this is actually the case, is still a matter of debate. Bruno Latour, for instance, concludes "that the data to be gathered in order to prove the advent of a substantial phenomenon called re-modernization are not easy to come by and, so far, are not thoroughly convincing." (Latour 2003: 45). In the case of animal husbandry however, the fact that societal debate enters a stage in which a diversity of fundamental characteristics of the system have become under scrutiny (and not only by those professionally engaged in the matter), does give evidence for the actual occurrence of such a phenomenon or re-modernization. The awareness is growing that the whole 
range of 'unintended side effects' of animal husbandry cannot possibly be solved by a mere adaptation of current knowledge and technology, farming practices, legislation and consumption practices, but demands a more thorough scrutiny of the presuppositions on which the sector had thrived for decades.

But can this be done? Reflexive modernization in its prescriptive formulation is the idea or masternarrative that modernization indeed can be done better, using the best of our reason to pre-empt and mitigate side effects while maintaining the benefits of earlier modernization efforts. It is the optimistic belief that we can improve on our current practices in such a way, that we do not repeat mistakes of the past, like the negligence of rebound and side effects. And that this is possible by increasing the reflexive character of our modernization efforts: a systematic and continuous scrutiny of the assumptions from which we think, plan and act.

This is, of course, quite ambitious in a complex world, that is changing rapidly, in which all kinds of hidden links may pop up any time and human rationality is bounded. No one can claim to oversee the whole, not to say the future. Nonetheless, we think it is worth trying. And we see at least four reasons, why a sustainable future for animal production needs an increased level of reflexivity. Firstly, increasing sustainability in animal husbandry requires simultaneous changes on several, very different dimensions of sustainability. If we don not, we run the risks of losing on one side, what we win on the other. Think for instance of the possible contradictions between increasing efficiency and improving animal welfare. Thus, any novelty should be designed for, and assessed on its effect on multiple dimensions. Secondly, increasing sustainability in animal husbandry requires the inclusion of an increasing number of stakeholders and actors (including animals). This requires a redefinition of the functions of the system at hand, and of the roles of these actors within that system. In fact it means a redefinition of the system boundaries and the relation between the systems at hand and the outside world (or 'super system'). Thirdly, first modernization of animal husbandry has resulted in a range of deeply entrenched beliefs, seemingly self-evident practices and goals, material and institutional standards that will limit the range of solutions if left unquestioned. And fourthly, any redesign of animal husbandry will necessarily involve the implicit or explicit embedding of values, either new, old or redefined (Feenberg 1999). Explication of this process should be maximized, for reasons of both legitimacy as well as successful implementation.

As will already be clear from the reasons above, reflexive modernization of socio-technological systems implies a rearrangement of established structure on what can be called the regime level. In the multi-level perspective (MLP; Rip and Kemp 1998; Schot 1998) socio-technical developments on three levels are distinguished: 1 . niche experiments, which are more or less 'liberated' from the rules pertaining to the existing regime; 2 . the socio-technological regime, which are stabilized patterns of artefacts, institutions, rules and norms assembled and maintained to perform economic and social activities (Berkhout, Smith, and Stirling 2004); and 3. the 'landscape': exogenous trends that may influence developments on the other two levels.

Investigating, analysing and describing socio-technological developments in these terms is one thing, purposefully 'doing' reflexive modernization is something different. System innovations involve changes in action as well as structure. The duality of structure (Giddens 1984; Stones 2005) indicates that, in principle, such a 'system innovation' is possible. In practice, however, conscious action to change an existing structure will face considerable resistance (Bos and Grin forthcoming). Sociotechnological regimes derive their stability from the cognitive, normative and formal rules, guiding the perception and action of actors (Nelson and Winter 1982; Dosi 1982). Actors and organizations will be embedded in interdependent networks that represent important organisational capital. Path dependencies and lock-ins will favor incremental changes rather than system innovations (Geels 2004). Thus, if one wants to consciously work towards sustainability by contributing to system innovations in existing practices, one needs a more elaborate and practical methodology. The multi-level perspective stresses the importance of creating niches, that temporarily shield promising novelties from the resistance existing sociotechnical regimes will exert. The approach presented here suggests a structured way of designing and introducing such novelties, based on a more elaborate idea on how to address and integrate a normative ideal like sustainability.

\section{Reflexive interactive design}

Reflexive interactive design (RIO in Dutch) is an approach for doing reflexive modernization (Bos and Grin forthcoming). It is a specific form of deliberative or participatory technology assessment 
(Gutmann and Thompson 1996; Grin, Van de Graaf, and Hoppe 1997; Bellucci and Bellucci 2002) that adopts design of both technical and social features of societal systems for production and consumption as its central activity and focus of deliberation. In this way, definition of both the problem and the solution takes place in a reciprocal and iterative argumentative exchange between the actors involved. Those actors may be the actual stakeholders, but also those people needed for implementation of the solution. As Grin and Van de Graaf (1996) point out, the intended outcome should be understood neither as value consensus nor as a mere 'tit-for-tat' compromise, but rather as congruency: a course of action on the way modernization in a specific instance should proceed, that makes sense for each of the actors involved.

Deliberation therefore has an important place in RIO, but should transcend the more common involvement of stakeholders and co-producers in design. To reach congruency more is needed than negotiation and trade-off between different interests. The latter would be a repetition of the way modernity tried to solve its problems. Deliberation requires that institutionally and technologically embedded assumptions, norms, knowledge claims, distinctions, roles and identities that are normally taken for granted must now be critically scrutinised.

$\mathrm{RIO}$ is an approach under construction. Parts of it are tested in previous projects (for instance Houden van Hennen 2004; Diergericht Ontwerpen 2003; Welzwijn 2006). The core of RIO is to introduce feasible novelties in existing socio-technological systems in order to contribute to significant, structural change ('system innovation') that enables the attainment of multiple goals, for instance in terms of sustainability. The novelties it creates should not be seen as mere technical replacements, neither as a technical fix. RIO is aiming at redesign, in order to reduce the number of trade offs between seemingly conflicting needs, and the number of system failures that have been built up during years of coevolution.

The RIO approach is based on various sources in innovation and policy sciences (Grin, Van de Graaf, and Hoppe 1997; Grin 2005; Grin and Van Staveren 2007; Schot 1992; Rip and Kemp 1998; Loorbach 2007; Rotmans 2003; Weaver et al. 2000), as well as more technically oriented methods from animal science (Bracke, Spruijt, and Metz 1999) and agricultural engineering (Siers 2004; De Beer 1997). The aim of RIO is to deliberately construct propositions for new socio-technical systems that are feasible in the first instance to ignite niche experiments in the foreseeable future, and have a good chance of contributing to structural reform in the long term.

$\mathrm{RIO}$ is reflexive by design. Actors involved gain knowledge by reflection on needs and presuppositions and the analysis of dominant structures. In every-day life we work within those structures on the basis of those presuppositions, mostly without making matters problematic. By making them explicit, the problem space and solution space for actors is increased (Voß and Kemp 2005).

$\mathrm{RIO}$ is interactive because it is via interaction with the people concerned in the problem area. This interaction is necessary to prevent substantive value bias (Feenberg 1999) and to increase the chances of realizing a structural reorientation. Thus in RIO, design means more than just the work of an engineer, designer or architect - it is also focused on a form of social engineering that goes beyond hard 'technical' outcomes and structures.

\section{Focus on needs}

In RIO the needs of central actors in the system to be designed play a pivotal role, for methodical and substantial reasons. Methodically, needs are the starting point in the systematic design methodology by Van den Kroonenberg called Methodisch Ontwerpen (Dutch for Structured Design: Siers 2004; De Beer 1997). Structured Design (SD) is an attempt to make the design process of artefacts like buildings and machinery more rigorous and traceable. Van den Kroonenberg was dissatisfied with the rather intuitive way architects and engineers tend to translate functions and requirements into concrete designs and artefacts. SD emphasizes the importance of a rigorous analysis of the actors and users, their needs, and of translating these into an elaborate set of quantitative requirements, based on traceable sources. A thorough system analysis of the functions and processes in both the existing and desired situation results in the identification of a limited number of key functions that play a pivotal role. Thinking of solutions and design is postponed until this work is done. One of the benefits of this approach is, that the requirements are formulated independently of the perceived solution space, which leads to a wider range of options. Another benefit is, that the method stimulates more fundamental reflection on the needs of prospective actors. The method explicitly distinguishes functions that have to be fulfilled from requirements that have to be met, and puts problems in a new and different perpective. Solutions are different potential ways or tasks to fulfill functions. 
A substantial reason to take the needs of actors as a starting point lies in the origins and the current context of application of RIO: animal husbandry. One of the big current challenges here is the amelioration of animal welfare. In order to design for animal welfare, one has to operationalize it, and make eventual choices explicit. (Bracke, Spruijt, and Metz 1999) have proposed to use the notion 'need' as a basis for (objectifiable) criteria that can be used to assess animal husbandry systems in terms of their performance on animal welfare. Their basic assumption is, that if the needs of animals are fulfilled, their welfare is beyond doubt. This follows from their proposition that for animals only their emotional state is intrinsically relevant for their welfare. This needs approach of animal welfare is congruent with Structured Design.
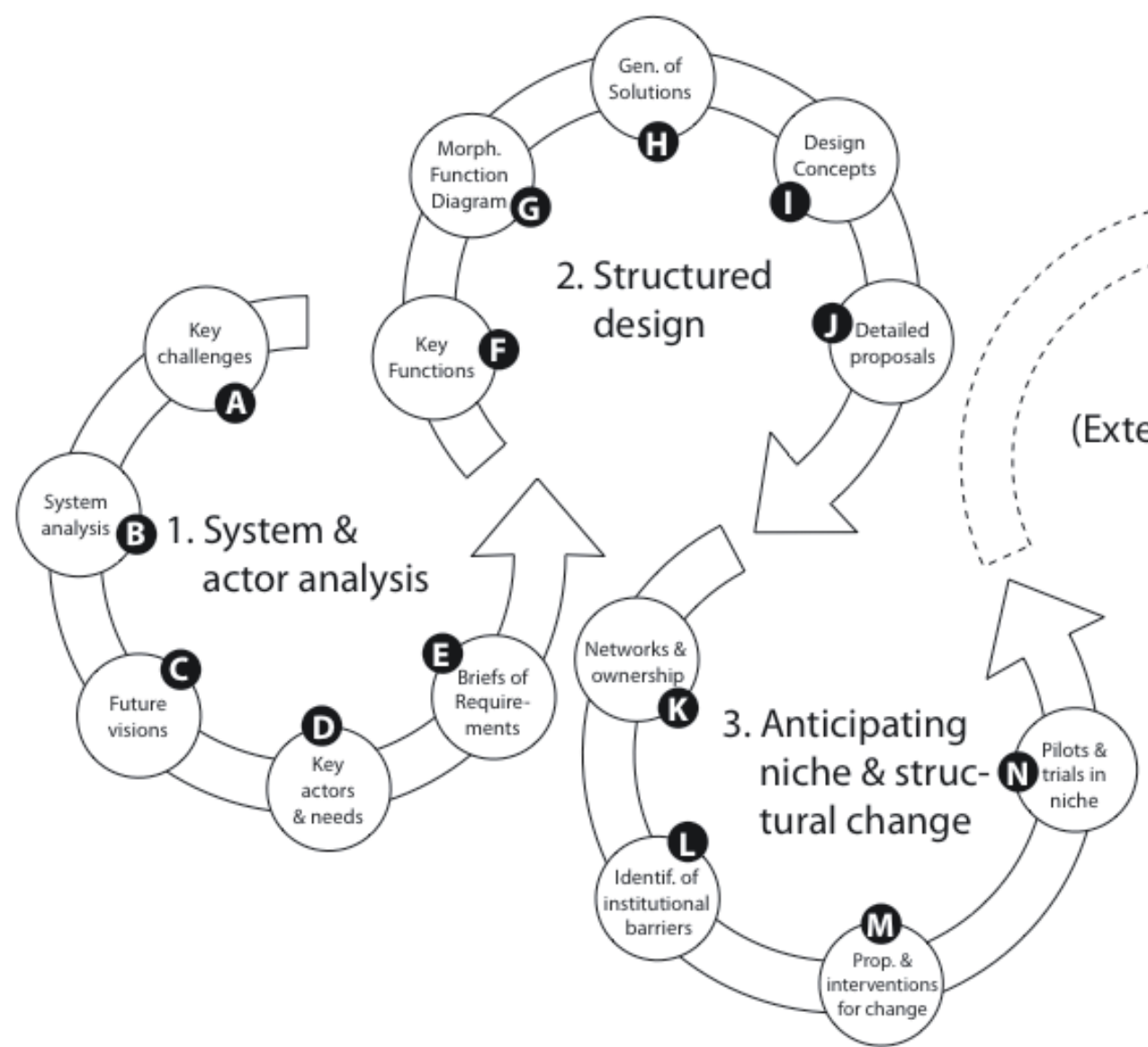

Figure 1: A schematic depiction of the three iteratively looped and linked cycles in RIO:

1. system and actor analysis; 2. structured design; and 3. anticipating niche \& structural change. Specific activities per cycle are detailed below.

The general approach of RIO is built upon three cycles of activity that may be fed back and fed forward on one and another (Figure 1):

1. System and actor analysis: systematic reflexion on the current structural arrangements of the system at hand, and the needs of key actors involved.

This is done analytically as well as in an interactive fashion, in order to facilitate opening up of the problem and solution space (Voß and Kemp 2005). The main activities are:

a. Identification of key challenges to be solved (for instance in relation to sustainability);

b. Systematic analysis of functions and processes and their relation in the current and desired situation. Identification of causal relations that prevent solution of these challenges in the current system (so called 'wicked links' (Grin and Van Staveren 2007). Identification of possible structural rearrangements in which wicked links are decoupled;

c. Interactive formulation of attractive future visions in which main challenges are addressed;

d. Identification of key actors (human and non-human) involved in proposed system, assessment of basic needs 
e. Formulation of a Brief of Requirements (BoR) per actor based on needs;

2. Designing new systems or arrangements using Structured Design (Siers 2004).

This is done in an interactive way, in order to incorporate practical and tacit knowledge, and prevent a research bias in value incorporation. The results are feasible and attractive concepts that might be realized in the near future. The main activities are:

f. Selection of key functions that are pivotal to realize the desired situations (i.e. future visions)

g. Composition of a structured morphological function diagram, in which functions are arranged.

h. Identification and generation of a range of (new or existing) solutions per key function. Creativity is involved.

i. Making a number of design concepts or drafts of new systems by combining single solutions into new structures

j. Elaboration into a detailed proposal (that addresses technical as well as social aspects). Evaluation of the drafts against the brief of requirements

3. Anticipating niche and structural change: strategically using concepts and reflections to facilitate effective reformism (Roep, Van der Ploeg, and Wiskerke 2003), i.e. realization of niches, as well as proposals and interventions for structural changes in the current system that create the space for changes in daily practice.

k. Establishment of networks of stakeholders around the concepts in general, and around specific solutions. Ideally, this is a natural result of previous interaction in cycles 1 and 2 .

I. Identification of barriers at the regime level (social, institutional, cultural) that may hinder niche formation and the realization of future visions.

$\mathrm{m}$. Proposals and actual interventions in order to lower or remove barriers at the regime level.

n. Establishment of pilots and trials in niche experiments.

These three cycles do not represent a chronology in time, although the main focus in RIO projects will change over time from the first to the latter. Due to both the reflexive and the interactive character, several iterative cycles may be completed during time, in which problems may become redefined, proposed structures are reassessed, and new actors shed new light on the proposed solutions.

The cylces are accompanied by and reflexively monitored based on an explication of the 'intervention theory' of the project. This 'theory' makes explicit to participants what the expected result in terms of tangible output and effective outcome ('external effects' in Figure 1) will be in the short, middle and long term. The intervention theory guides strategic choices throughout the project.

\section{RIO and the Power of Cows (Kracht van Koeien)}

The present case is a project on sustainable dairy production, called Kracht van Koeien ('Power of Cows' in Dutch). The project is meant to deliver new concepts for dairy production that improve on sustainability in more than one respect simultaneously. The Dutch Ministry of Agriculture gave the assignment, in order to have feasible concepts for maintaining the Dutch dairy sector, while realizing significant improvements in animal welfare and environmental issues. The project started in 2007 therefore, only preliminary results can be given on the work done. For more information on the next phases, see papers on an earlier project Laying Hen Husbandry (Groot Koerkamp and Bos forthcoming; Bos 2008).

\section{Problem (re)definition}

The problem definition of the project was not clearly stated beforehand. Contributing to a 'more sustainable' dairy production serves as a very general guideline for the assignment, but the extent and substantive content of this sustainability requirement was not specified, and is to be identified during 
the process, as a synthesis of problem perceptions of a diversity of stakeholders. Based on a literature review, expert meetings and sessions with farmers, farmer representatives and other central stakeholders, the challenges for sustainability of the current dairy production system were assessed. The result was fed back as a proposition to a panel of representatives (the 'platform') for discussion.

The challenges can be summarized as (1) a reduction of the considerable environmental footprint (deposition of nitrate in soil and surface waters, emissions of ammonia, the production of greenhouse gases like methane and nitrous oxide); (2) improvement of animal welfare and health issues (claw disorders that affect the majority of cows in current systems, leading to locomotion problems; mastitis infection of the udders; a general trend towards intensification of dairy production and consequently keeping cows inside year round without grazing); (3) economical challenge to reduce costs, caused by liberalisation and globalisation of the dairy market; (4) find an answer / deal with for the increasing competition on land and space, with a resulting big gap between economical value and agricultural value of land; (5) overcome the increasing constraints on the availability of (especially cheap or nonpaid) labour force.

\section{System analysis}

Most of these challenges are hardly new to those involved, except maybe for the contribution to global warming. The most likely explanation for this persistence is that they are deeply rooted in the basic structure of the dairy production system, and are almost inherently connected with some desirable effect. A system analysis was performed to assess the causal origins of the challenges and their interconnectedness, an approach suggested by Grin and Van Staveren (2007). Two system levels (In 't Veld 1974) were distinguished: the (local) husbandry system (including cows, land, farmer and physical infrastructure) and the dairy sector in the Netherlands as an aggregate system, but did also include important relations to the wider (national, European and global) environment (like soy bean production, fertilizer, market conditions, and competition with biomass and fuels). The system analysis was subdivided into the following components:

a. defining the system boundaries, the adequate system level and elements (living \& dead) in relation to the problem and goals; and defining the systems approach: top-down starting from the complete system, or bottom-up starting from the elements, or iterating between these two.

b. historical origins of the character of current dairy production systems; Husbandry systems are dynamic transient systems, meaning that the current output of the system is not only the results of the current state of the system, but also from states in the past.

c. identification of 'wicked links', i.e. deeply entrenched couplings of desired effects and undesired side-effects;

d. assessment of important trends (inside and outside the system itself) that may affect sustainability of dairy production in the future;

As any technological system, the dairy production sector has a fundamentally heterogeneous character. Its structure is built from the interaction between living entities and non-living matter and (technical) artefacts. Its operational functions, as well as its developmental path are aligned by a sociotechnical regime, in which economical, as well as deeply entrenched cultural features play important roles. It has a range of different system functions (i.e. those functions that serve goals and fulfil needs outside itself) that exceed the sole production of milk and dairy products. Finally, the dairy system is a significant stakeholder in Dutch spatial planning, because of the large amount of privately owned land. Due to this complexity, any system analysis will fail to cover the whole. In this case, the system was analysed from different angles (socio-technological, cultural, historical) with the aim to get a better understanding of the structural roots of the main challenges in the system. Below, eight important structural characteristics of the dairy sector in the Netherlands are presented, that lie at the root of the challenges identified, and that serve as starting points for the next design steps in the project.

\section{Historically co-evolved characteristics}

1. For historical reasons, Dutch dairy has focussed on bulk milk production as the primary goal, instead of (for instance) meat and milk at the same time. The main reason is the heavy EU subsidies for milk from the sixties and onwards. The system (including the stock of knowledge, breeding, technology and farmer's status) has co-evolved around this. Another consequence is that the system never really had to compete on price, partly coupled with the EU milk quota system. This is changing with increasing market liberalisation; 
2. This history lead to an emphasis on the breeding of highly productive cows as the most important strategy to increase income per cow, without the parallel attention on the conditions (housing, management, feed) that are to be met to sustain these yields without compromising on health, life expectancy or welfare of the animals. This has resulted in several health problems with 'epidemic' proportions: claw disorders and locomotion problems, reduced fertility and mastitis.

\section{Wicked links}

3. Efficiency and yield of cows could be increased by the availability of cheap proteins and energy from other parts of the world, in close connection with imports for human consumption (soy). This resulted in net local surpluses of reactive nitrogen (i.e. all nitrogen that can be chemically reactive, like $\mathrm{N}_{2} \mathrm{O}, \mathrm{NH}_{3}, \mathrm{NO}_{3}$ and $\mathrm{NO}_{x}$ ) and phophorus.

4. Artificial fertilizer (AF) has a privileged position in EU-regulation, and its application in agriculture is much more optimized than the application of manure. Therefore, despite the surpluses of reactive nitrogen, $A F$ is still used on a massive scale in agriculture, while $A F$ is produced against high energetic costs and is a significant contributor of emissions of $\mathrm{N}_{2} \mathrm{O}$, one of the strongest green house gases known.

5. The fundamental choice of using ruminants for producing protein, in order to upgrade lowgrade vegetable sources like grass into proteins suitable for human consumption, is fundamentally coupled to the production of methane from the fermentation process inside the cow.

6. The belief that growth (in number of cows per farm) is the only way to make the farm future proof, a thought fed by advisors, the historical records and the fact that 'larger' farms tend to have lower costs than smaller ones. At the same time, economical figures suggest that growing bigger is not the same as being bigger, and thus seem to refute the idea that growth is a sensible strategy in the majority of cases.

7. A deeply entrenched belief that is necessary to earn a complete family income from the farm. Combined with the fact that labour is still largely unpaid, this is one of the driving forces to increase the size of farms, with the parallel reduction of net income per hour and free time.

\section{Relevant trends}

8. Spatial policy in the Netherlands puts constraints on size and appearance of buildings. In combination with heavy competition and speculatively high prices for land (also partly due to the character of national spatial planning) puts considerable pressure on reduction of the space per cow (at least in the winter) because of the (perceived) costs.

9. Increasing difficulties to transfer a farm to a successor, because of its increasing capital intensity (mainly property of land).

\section{Identification of possible structural rearrangements and key functions}

According to the assignment, new feasible concepts should be delivered, that imply a considerable improvement on more than one dimension of sustainability. And as they should be feasible, they should be able to fit in one or another economical model that will drive its application in real life.

The first step to accomplish this was to identify the possibilities to decouple so-called 'wicked links' (nrs. 3-7 in the previous list). In RIO a distinction is used between needs, the system functions and actor functions to fullfill those needs, operational functions that maintain the system, the actual solutions for those functions, and the effects of these solutions. Specific solutions may have desired and (sometimes undesired) side effects. In that case we speak of a wicked link.

But how to unlink a desired effect from an (undesired) side effect? This was investigated using the following heuristics. Four ways, meant as heuristic guidelines for creative assessment, not as fool proof methods.

Firstly, one can think of a replacement of the solution that is most close to the generation of the undesired effect. For example by the regional production of concentrates, which reduces the net surplus of reactive $\mathrm{N}$ in the system. It might even turn out that the historical conditions that laid the basis for the existence of this solution (for instance the cheap price of imports, or the need for chemical fertilizer in western countries), actually do not exist anymore or will vanish in the near future. 
Secondly, one may redefine the need, the function for which the solution exists, in order to make the solution superfluous. For example: a redefinition of growth in number of (smaller) units, or in a system of shares in other dairy farms, instead of cows per unit. If growth is a desired effect that stakeholders want to facilitate, the solution space is opened up, by extending the concept itself.

Thirdly, one can critically assess the need that the function is supposed to fulfil. For instance: do we need milk, or do we rather need protein? If the latter is the case, is it possible to produce the same kind of protein from grass without the 'solution' of cows or ruminants in general?

And fourthly, one can turn an undesired effect into a desired one, by introducing a new system function. An example of this is the redefinition of a surplus of reactive $\mathrm{N}$ (manure as waste), into a possible resource (manure as food) for a product that is highly needed in other parts of the world, competing with artificial fertilizer. This resembles the heuristic strategy proposed by (McDonough and Braungart 2002) called Cradle to Cradle.

Subsequently, the key functions were identified that a proposed system should be able to perform in an adequate way. The goals for dairy production were translated into two main functions, being milk production and production of highly valuable nutrients like nitrogen and phosphorus. Three subfunctions were identified, being production of energy, production of meat and by-products, and the contribution to a valuable cultural landscape and nature. The system analysis in the case of milk production in the Netherlands revealed that the following key functions are vital to redesign the system and have to be paired with better solutions: produce grass; produce concentrates or substitute; graze pastures; house cows; manage husbandry system; maintain cow health / manage cow diseases; generate farmers' income; allow for easy access to capital; generate labour; collect, manage and store urine and faeces; produce energy (by photovoltaic, wind, biomass); generate plant nutrients (nitrogen and phosphorus).

\section{Combination into outlines of attractive futures}

The second step was the combination of a number of promising structural rearrangements into a number of future visions, that might be attractive for a variety of actors (or their spokesmen) involved in the current system, and bear the promise to solve a number of the challenges identified earlier. These future visions did not and should not have to be complete solutions or blue prints, since their function is to provide an inspiring working proposition (the 'dreams') for the next phases, that can and should be shared and altered by the actors involved. The project team consciously proposed several combinations, in order to prevent an unsubstantiated universalistic approach to a complex system with a lot of variety in actors and their respective needs. Most of the actors were already identified and involved in the earlier phase of the problem definition, but the range can be broadened along the road, as new affected or involved actors emerge from the analysis. At the present point, these outlines are work in progress, and will be presented at the conference.

\section{Investigation of actors and their needs}

Once future visions have been formulated and assessed by a multiplicity of actors involved (including spokespeople for animals, nature and the environment), a Brief of Requirements (BoR) is formulated for each actor that can be identified to be part of the system, served by or affected by the (proposed) system. Their needs will be assessed using interviews and workshops (in the case of human actors like farmers), scientific and practical knowledge (in the case of animals), or a combination of qualitative and quantitative techniques (in the case of citizens/consumers). In any case, needs are never taken at face value, but will be abstracted as far as possible, to prevent solutions to be mixed up with needs and specific requirements. Subsequently, needs are quantified and qualified into requirements in the BoR, as a yard stick for the designs. As far as possible, the BoR's will be checked in interaction with those involved. Further information on this can be found in (Bos and Groot Koerkamp forthcoming). This work is partly done already at the moment of submitting this paper. Results will be presented at the conference. For an outline of the subsequent phases, see section 4.

\section{Intervention theory}

Despite the rigor involved, these ideas or novelties will not and cannot in themselves change entrenched structural arrangements. This would suggest an overly optimistic belief in technology or rationality. Interactive design of feasible concepts is a conscious intervention into an existing and stabi- 
lized system. Both the ideas, as well as the process that lead to them have to be starting points for structural change. Any action during the process thus will be assessed on its potential capacity to do this. This cannot be planned in detail beforehand, but some general aims can be identified. We call this the 'intervention theory' of the project team: the set of goals and hypotheses that will guide the interaction of the project with the outside world. The team identifies this theory beforehand, in order to evaluate the project's success later, and to be explicit about its goals.

Main project goal

1. Contributing to the development of sustainable dairy production in the Netherlands, by introducing visions, design concepts and substantiated inventories of needs and requirements that enable specific (networks of) stakeholders to realize structurally different and more sustainable practices in and around dairy husbandry in the Netherlands.

Subsidiary project goals

2. Facilitation of coordinated action and learning, by introducing two or more feasible future visions for sustainable dairy production, that bear a reasonable promise of solving a number of current sustainability issues, and that may function as integrated frameworks for change experiments because of their are attractiveness to a range of stakeholders;

3. Briefs of Requirements (BoR's) that explicate and quantify the needs and requirements of important actors in and around future dairy production (like the cow and 'the' farmer).

4. Two or more feasible and elaborated designs for key parts of the future visions, such as husbandry systems, or new arrangements of capital and ownership, based on the BoRs.

5. Formation of networks of actors with a direct stake or ideal in the realization, around future visons, and around specific design proposals as parts of these visions.

Main activities

6. See sections 4 and 5 .

Output

7. Future visions \& Designs: visual and textual media.

8. Briefs of Requirements: scientific and popular versions.

9. Publications in scientific and popular journals of intermediate and end results, to share results, as well as to stimulate debate on the future face of dairy production.

Short term outcome

10. Sectoral and societal perspective on sustainable dairy husbandry enriched by alternatives, that are perceived as feasible and desirabe, igniting involvement of front runner stakeholders.

11. BoR of the Dairy Cow has set the bar for a desirable level of animal welfare.

12. BoR of the Farmer has deepened sectoral dialogue on issues of growth, and labour (quality).

13. New connections perceived between market and production, by the integration of needs and perceptions derived from consumer/citizen studies into designs.

14. Networks of stakeholders working on specific parts or future visions. Ideally combination of or close collabation with existing networks on specific issues in dairy production.

Mid term outcome

15. Niche experiments and proofs of principle in real life situations of the designs for key parts (4).

16. Policy effects on regulation of minerals, animal welfare and spatial planning.

17. A broadened perspective of farmers, advisors, knowledge workers and administrators on possible futures of dairy farms (more than the three alternatives that are generally seen now). 


\section{Afterthought}

Reflexive Interactive Design is a structured approach to contribute to effective reformism (Roep, Van der Ploeg, and Wiskerke 2003) of existing systems. Some elements of the approach are in place and tested (for instance the structured design and the needs approach), others are under construction (like the system analysis, the conception of systems, functions, requirements and effects; as well as the way to come to future visions), and still others are largely based on intuition and previous experience (like the strategic use of concepts and process in effective reformism). This notwithstanding, consciously designing projects for structural change in existing complex systems is rather new. RIO attempts to synthesize the insights of such diverse sources as ethology, engineering, social theory and science and technology studies in a coherent whole. This interdisciplinary attempt may make some people angry, for their professional criteria for quality are difficult to apply. This is however inherent to interdisciplinary work. With this paper, we hope to have elicited a response of those, that are involved in the deliberate change of our current production systems, or are interested to do so.

\section{References}

Beck, Ulrich. 1992 (1986). Risk Society: Towards a New Modernity. London: Sage Publications Ltd. 1997. The re-invention of politics. Rethinking Modernity in the Global Social Order. Cambridge: Polity Press.

Beck, Ulrich, Wolfgang Bonss, and Christoph Lau. 2003. The Theory of Reflexive Modernization. Problematic, Hypotheses and Research Programme. Theory, Culture \& Society 20 (2):1-33.

Beck, Ulrich, Anthony Giddens, and Steven Lash. 1994. Reflexive modernization. Cambridge: Polity Press.

De Beer, J.C.F. 1997. Methodisch Ontwerpen: Academic Service.

Bellucci, J., and S. Bellucci. 2002. Participatory technology assessment: European perspectives. London: Centre for the Study of Democracy.

Berkhout, Frans, Adrian Smith, and Andy Stirling. 2004. Socio-technical regimes and transition contexts. In System Innovation and the Transition to Sustainability: Theory, Evidence and Policy, edited by B. E. Elzen, F. W. Geels and K. Green. Cheltenham: Edward Elgar.

Bos, A.P. (Bram). 2008. Instrumentalization Theory and Reflexive Design in Animal Husbandry. Social Epistemology 22 (1):29-50.

Bos, A.P. (Bram), and John Grin. forthcoming. "Doing" Reflexive Modernization in Pig Husbandry: The Hard Work of Changing the Course of a River. Science, Technology, \& Human Values.

Bos, A.P. (Bram), and Peter W.G. Groot Koerkamp. forthcoming. Synthesizing needs in system innovation through methodical design. A methodical outline on the role of needs in Reflexive Interactive Design (RIO).

Bracke, Marc B.M., Berry M. Spruijt, and Jos H.M. Metz. 1999. Overall animal welfare assessment reviewed. Part 3: Welfare assessment based on needs and supported by expert opinion. Netherlands Journal of Agricultural Science 47:307-322.

Diergericht Ontwerpen, Projectgroep. 2003. Welzwijn in de toekomst, over varkenswensen voor varkensstallen. Wageningen/Lelystad: Wageningen UR.

Dosi, Giovanni. 1982. Technological paradigms and technological trajectories; A suggested interpretation of the determinants and directions of technical change. Research Policy (11).

Feenberg, Andrew. 1999. Questioning Technology. London: Routledge.

Geels, Frank W. 2004. From sectoral systems of innovation to socio-technical systems; Insight about dynamics and change form sociology and institutional theory. Research Policy (33):897-920.

Giddens, Anthony. 1984. The Constitution of Society. Outline of the Theory of Structuration. Cambridge etc.: Polity Press. 
Grin, John. 2005. Reflexive modernization as a governance issue - or: designing and shaping Restructuration. In Reflexive Governance for Sustainable Development, edited by J.-P. Voß, D. Bauknecht and R. Kemp. Cheltenham: Edward Elgar.

Grin, John, and Henk Van de Graaf. 1996. Technology Assessment as Learning. Science, Technology \& Human Values 21 (1):72-99.

Grin, John, Henk Van de Graaf, and Rob Hoppe. 1997. Technology assessment through interaction: a guide. Den Haag: SDU.

Grin, John, and Arienne Van Staveren. 2007. Werken aan systeeminnovaties. Lessen uit de praktijk van InnovatieNetwerk. Assen: Van Gorcum.

Groot Koerkamp, Peter W.G., and A.P. (Bram) Bos. forthcoming. Designing complex and sustainable agricultural production systems; an integrated and reflexive approach for the case of table egg production in the Netherlands. NJAS - Wageningen journal of life sciences.

Gutmann, A., and D. Thompson. 1996. Democracy and disagreement. Why moral conflict cannot be avoided in politics, and what should be done about it. Cambridge, MA \& London: The Belknap Press of Harvard University Press.

Houden van Hennen, Project team. 2004. Laying hen husbandry -- towards a happy hen life, proud farmers and a satisfied society. Wageningen - Lelystad: Wageningen UR.

Latour, Bruno. 2003. Is Re-modernization Occurring - And If So, How to Prove It? A Commentary on Ulrich Beck. Theory, Culture \& Society 20 (2):35-48.

Loorbach, Derk. 2007. Transition Management. New mode of governance for sustainable development. Utrecht: International Books.

McDonough, William, and Michael Braungart. 2002. Cradle to Cradle: Remaking the Way We Make Things. New York: North Point Press.

Milieudefensie, and Jongeren Milieu Actief. 2007. Boeren met toekomst. Burgerinitiatief Stop fout vlees. Amsterdam: Milieudefensie.

—. 2008. Stop fout vlees 2007 [cited 16-03-2008 2008]. Available from http://www.stopfoutvlees.nl/.

Nelson, R.R., and S.G. Winter. 1982. An Evolutionary Theory of Economic Change. Cambridge MA: harvard University Press.

Rip, Arie, and René Kemp. 1998. Technological change. In Human Choice and Climate Change, Volume // edited by S. Rayner and E. L. Majone. Washington D.C.: Batelle Press.

- 1998. Technological Change. In Human Choice and Climate Change, edited by S. Rayner and E. L. Malone. Washington D.C.: Batelle Press.

Roep, Dirk, Jan Douwe Van der Ploeg, and J.S.C. (Han) Wiskerke. 2003. Managing technicalinstitutional design processes: some strategic lessons from environmental co-operatives in the Netherlands. NJAS - Wageningen journal of life sciences 51 (1/2):195-217.

Rotmans, Jan. 2003. Transitiemanagement: sleutel voor een duurzame samenleving. Assen: Van Gorcum.

Schot, Johan W. 1992. Constructive Technology Assessment and Technology Dynamics: The case of clean technologies. Science, Technology, \& Human Values 17 (1):36-56.

1998. The usefulness of evolutionary models for explaining innovation: the case of the Netherlands in the 19th century. History and Technology 14:173-200.

Siers, F.J. 2004. Methodisch ontwerpen volgens H.H. van den Kroonenberg. Amsterdam: WoltersNoordhoff.

Steinfeld, Henning, Pierre Gerber, Tom Wassenaar, Vincent Castel, Mauricio Rosales, and Cees de Haan. 2006. Livestock's Long Shadow. Environmental Issues and Options. Rome: FAO.

Stones, Rob. 2005. Structuration Theory. Basingstoke and New York: Palgrave MacMillan.

Thieme, Marianne L. 2008. Meat the Truth. Nicolaas G. Pierson Foundation 2007 [cited 16-03-2008 2008]. Available from http://www.meatthetruth.nl/. 
In 't Veld, J. 1974. Systeem en modelbegrippen, systeembenadering van bedrijven en instellingen, procesbeheersing (in Dutch). Delft Technische Hogeschool Delft.

Verburg, Gerda. 2008. Toekomstvisie op de veehouderij, Den Haag: Ministerie van LNV.

Voß, Jan-Peter, and René Kemp. 2005. Reflexive Governance: Learning to cope with fundamental limitations in steering sustainable development. In ESEE conference. Lisbon.

Weaver, P., L. Jansen, G. Van Grootveld, E. Van Spiegel, and P. Vergragt. 2000. Sustainable technology development. Sheffield: Greenleaf Publishing.

Welzwijn, Projectgroep. 2006. Welzwijn wel doen. Vernieuwingsinitiatieven in de varkenshouderij. Wageningen/Lelystad: Wageningen UR. 
